\title{
A PEOPLE PASSING RUDE: \\ BRITISH RESPONSES TO RUSSIAN CULTURE
}

Edited by

Anthony Cross

\section{$\underset{\text { OpenBook }}{\text { Publishers }}$ [I]}




\section{$\underset{\text { Publishers }}{\text { OpenBook }}$}

Open Book Publishers CIC Ltd.,

40 Devonshire Road, Cambridge, CB1 2BL, United Kingdom

http://www.openbookpublishers.com

(C) 2012 Anthony Cross et al. (contributors retain copyright of their work).

The articles of this book are licensed under a Creative Commons

Attribution-NonCommercial-NoDerivs 3.0 Unported License

http://creativecommons.org/licenses/by/3.0/

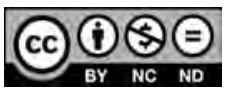

Some rights are reserved. This book and digital material are made available under the Creative Commons Attribution-Non-Commercial-No Derivative Works 2.0 UK: England \& Wales License. This license allows for copying any part of the work for personal and non-commercial use, providing author attribution is clearly stated. Details of allowances and restrictions are available at:

http://www.openbookpublishers.com

As with all Open Book Publishers titles, digital material and resources associated with this volume are available from our website at:

http://www.openbookpublishers.com/product/160

ISBN Hardback: 978-1-909254-11-4

ISBN Paperback: 978-1-909254-10-7

ISBN Digital (PDF): 978-1-909254-12-1

ISBN Digital ebook (epub version): 978-1-909254-13-8

ISBN Digital ebook (mobi version): 978-1-909254-14-5

Cover image: Russians Teaching Boney to Dance, a caricature by George Cruikshank published on 18 May 1813 and adapted from an original 1812 caricature by Ivan Terebenev. An early example of a British response to Russian art! By kind permission of the Anne S.K. Brown Military Collection, Brown University Library.

Every effort has been made to identity and contact copyright holders; any omissions or errors will be corrected if notification is made to the publisher.

All paper used by Open Book Publishers is SFI (Sustainable Forestry Initiative), and PEFC (Programme for the Endorsement of Forest Certification Schemes) Certified.

Printed in the United Kingdom and United States by Lightning Source for Open Book Publishers 


\section{Contents}

Page

Illustrations

Notes on contributors xiii

1. By Way of Introduction: British Reception, Perception and Recognition of Russian Culture Anthony Cross

2. Byron, Don Juan, and Russia Peter Cochran

3. William Henry Leeds and Early British Responses to Russian Literature Anthony Cross

4. Russian Icons through British Eyes, c.1830-1930 Richard Marks

5. The Crystal Palace Exhibition and Britain's Encounter with Russia Scott Ruby

6. An 'Extraordinary Engagement': A Russian Opera Company in Victorian Britain Tamsin Alexander

7. Russian Folk Tales for English Readers: Two Personalities and Two Strategies in British Translations of the Late Nineteenth and Early Twentieth Centuries Tatiana Bogrdanova 
8. 'Wilful Melancholy' or 'a Vigorous and Manly

Optimism'?: Rosa Newmarch and the Struggle against Decadence in the British Reception of

Russian Music, 1897-1917

Philip Ross Bullock

9. 'Infantine Smudges of Paint... Infantine

Rudeness of Soul': British Reception of

Russian Art at the Exhibitions of the

Allied Artists' Association, 1908-1911

Louise Hardiman

10. Crime and Publishing: How Dostoevskii

Changed the British Murder

Muireann Maguire

11. Stephen Graham and Russian Spirituality:

The Pilgrim in Search of Salvation

Michael Hughes

12. Jane Harrison as an Interpreter of Russian

Culture in the 1910s-1920s

Alexandra Smith

13. Aleksei Remizov's English-language Translators:

New Material

Marilyn Schwinn Smith

14. Chekhov and the Buried Life of Katherine Mansfield

Rachel Polonsky

15. 'A Gaul Who has Chosen Impeccable Russian as his Medium': Ivan Bunin and the British Myth of Russia in the Early 20th Century

Svetlana Klimova

16. Russia and Russian Culture in The Criterion, 1922-1939

Olga Ushakova

17. 'Racy of the Soil': Filipp Maliavin's London Exhibition of 1935

Nicola Kozicharow 
18. Mrs Churchill Goes to Russia: The Wartime

Gift-Exchange between Britain and the Soviet Union

Claire Knight

19. 'Unity in Difference': The Representation of

Life in the Soviet Union through Isotype

Emma Minns

20. 'Sputniks and Sideboards': Exhibiting the Soviet

'Way of Life' in Cold War Britain, 1961-1979

Verity Clarkson

21. The British Reception of Russian Film, 1960-1990:

The Role of Sight and Sound

Julian Graffy

Index 


\title{
20. 'Sputniks and Sideboards': Exhibiting the Soviet 'Way of Life' in Cold War Britain, 1961-1979
}

\author{
Verity Clarkson
}

Approaching Earls Court exhibition centre in the summer of 1968, visitors would have been struck by the bold initials 'USSR' on the familiar façade ${ }^{1}$ (fig. 20.1). They heralded the second of three Soviet 'Industrial Exhibitions', staged in 1961, 1968 and 1979, which brought striking Soviet cultural propaganda to London on a vast scale. ${ }^{2}$ Whereas the reciprocal British trade fairs in Moscow of 1961 and 1966 were based on expanding AngloSoviet commercial contacts and eschewed blatant propaganda, the Soviet shows proudly presented eye-catching 'prestige' displays of the communist 'way of life': gleaming space satellites, welding equipment, fashions, model sanatoria, aeroplanes and handicrafts. Official publicity claimed that these exhibitions would promote 'mutual understanding between the peoples of the Soviet Union and Great Britain'. ${ }^{3}$ But the responses of British government agencies and press indicate discrepancies between the projected socialist utopia and the image that was received.

This research was carried out as part of an AHRC funded Collaborative Doctoral Award at the University of Brighton and the Victoria and Albert Museum. I am particularly grateful to the staff at Earls Court \& Olympia (EC \& O) Venues for their assistance. Every effort has been made in conjunction with the archive at Earls Court to trace the copyright holder of these images. I would be grateful if anyone claiming copyright could notify the author so that corrections can be incorporated in future reprints or editions of this book.

1 On the impact of such façades, see Marla Stone, 'Staging Fascism: The Exhibition of the Fascist Revolution', Journal of Contemporary History, XXVIII, no. 2 (1993), pp. 215-43.

2 John Glanfield, Earls Court and Olympia: From Buffalo Bill to the 'Brits' (Stroud, 2003).

3 The National Archives (hereafter TNA) FCO 28/436 'Press release: The Soviet Exhibition Comes to Town: Massive Display for Earls Court 6-24 August 1968'. 


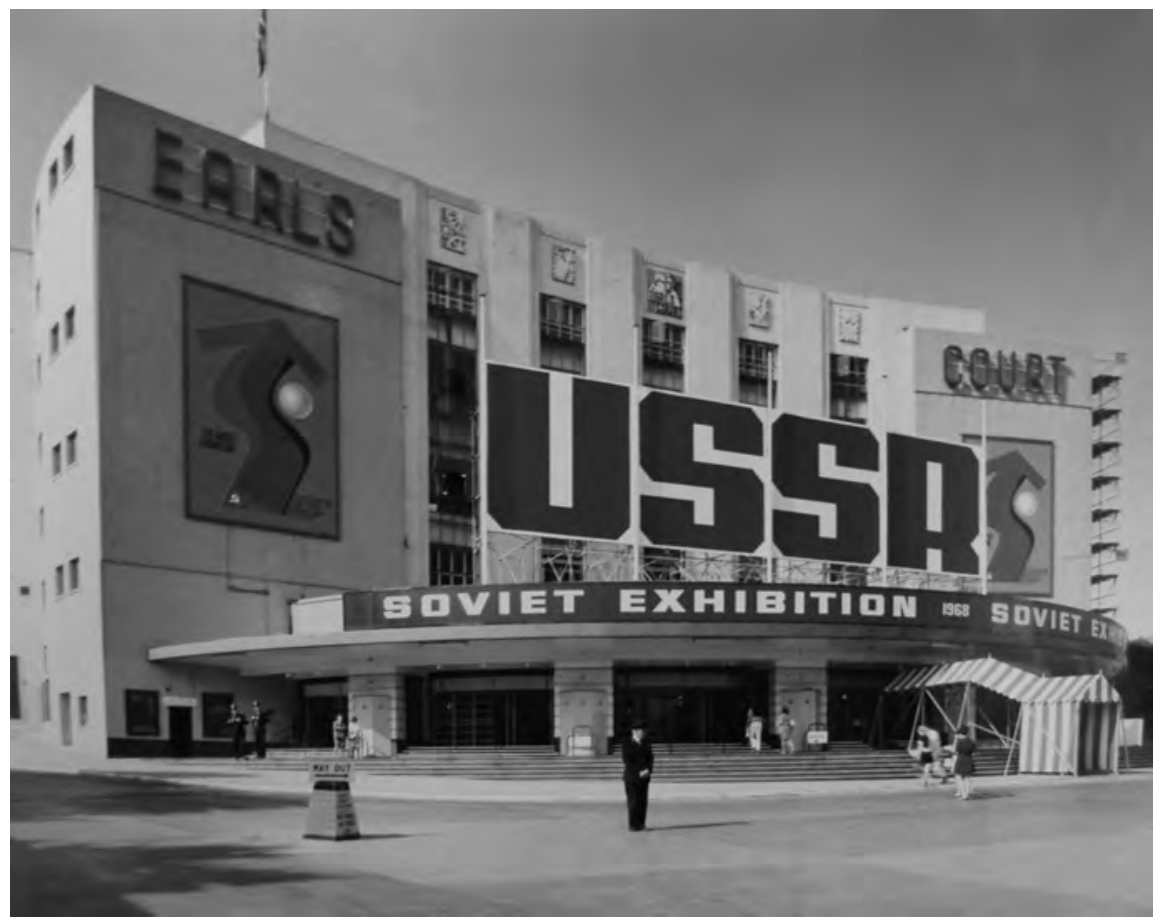

Fig. 20.1 Entrance façade of 'USSR at Earls Court' (1968). Press photo EC \& O Venues Archive.

Focusing mainly on the 1961 and 1968 shows, this paper investigates changing British perceptions of Soviet culture via an analysis of the presentation and reception of these illusory visions of life on the other side of the Iron Curtain. It explores the political and cultural background of the exhibitions, examining the concept of a 'way of life' as a type of illusion or myth-a 'dreamworld' - perceived differently by Soviet organisers and filtered through the preconceptions of receiving British audiences about the quality and availability of Soviet material culture. ${ }^{4}$ Addressing the content and press reception of the Soviet 'dreamworlds' created at Earls Court, it suggests that the reception of these exhibitions was coloured by existing British stereotypes about the Soviet Union and what types of things comprised an 'ideal' Soviet object in British eyes. Whereas in 1961 the Soviet 'dreamworld' could be separated from the political realities

4 To my knowledge, no record of audience composition or visitors' comment books survives. This paper utilises responses from published sources and The National Archives. 
and tensions of the Cold War and received as a playful, amusing childlike fantasy, by 1968 this fragile illusion could no longer be maintained. In conclusion, it considers the final exhibition where the Soviet 'way of life' on show was further distanced from British observers' perceived Soviet reality.

An understanding of the phrase 'way of life' is vital to appreciate how the Cold War was fought. Unlike a conventional 'hot' war, it has been explained as a conflict between the rival political, cultural and ideological systems of East and West. In the phase of 'peaceful coexistence' which followed the Thaw of the mid 1950s, competing representations of the standard of living under each system became vital propaganda, most famously at the 1959 'kitchen debate' between Khrushchev and Nixon at the American National Exhibition in Moscow. ${ }^{5}$ Displays of an idealised, modern 'everyday life' were presented at politically charged locations in both East and West. ${ }^{6}$ The Soviet Union staged such displays internationally from the late 1950s. Those held in London were typical in that they aimed to present a 'promising and reassuring myth' of the USSR. ${ }^{7}$ Consequently, the real and the represented material culture and living environments of the two blocs have become an important element of Cold War historical analysis. ${ }^{8}$

The British press used terms such as 'dreamland' to describe the fantastical 1968 Earls Court exhibition. ${ }^{9}$ A similar theme has been explored in academic discussions of the Cold War. ${ }^{10}$ Susan Buck-Morss has applied philosophy and critical theory to images from both East and West to unpick how 'dreamworlds' - two correlated visions of progress and modernityshaped both sides' understanding. ${ }^{11}$ The exhibitions in London can be seen as the Soviet 'dreamworld' made physical. It was not only a mass utopian

5 Walter L. Hixson, Parting the Curtain: Propaganda, Culture and the Cold War 1945-1961 (Basingstoke, 1997), p. 179.

6 Greg Castillo, 'Domesticating the Cold War: Household Consumption as Propaganda in Marshall Plan Germany', Journal of Contemporary History, XLII (2005), pp. 261-88.

7 Andrej Ikonnikov, 'Architektur und Utopie', in P. Noever \& MAK - Oesterreichisches Museum fur angewandte Kunst Wien (eds.), Tyrannei des Schönen: Architektur der StalinZeit (Munich and New York, 1994), p. 35, quoted in Sonja D. Schmid, 'Celebrating Tomorrow Today: The Peaceful Atom on Display in the Soviet Union', Social Studies of Science, XXXVI, no. 3 (2006), p. 334.

8 e.g. Susan E. Reid and David Crowley (eds.), Style and Socialism: Modernity and Material Culture in Post-War Eastern Europe (Oxford and New York, 2000).

9 'Into Dreamland', The Guardian (22 August 1968), p. 8.

10 See also the semi-fictional 'fairytale' by Francis Spufford, Red Plenty: Inside the Fifties Soviet Dream (London, 2010).

11 She utilises Walter Benjamin's concept of 'dreamworlds' as an analytical tool to explain the collective mental state of a population encountering the constant shifts of modern life 
illusion of how the USSR officially viewed itself, but also provided a space for British viewers to negotiate their Western dream of 'Russia': the 'dream that each side had about the other' during the Cold War. ${ }^{12}$ In creating this vision, the London exhibitions were part of the lineage of Soviet shows such as the Exhibition of the Achievements of the People's Economy of the USSR (VDNKh), which aided the 'creation and maintenance of a Soviet identity'. In the Soviet Union, such exhibitions provided a space in which Soviet visitors could witness a new, utopian reality that was believed to be imminent. ${ }^{13}$ In contrast, Western audiences witnessing exhibitions such as the 1959 Soviet show in New York were more conscious of the 'irreconcilability of reality with the image': it showed the USSR 'not as it is, but as it wishes to be'. ${ }^{14}$

British audiences at Earls Court received this 'dreamworld' by positioning it within existing discourses of what Soviet life was imagined to be like. Following World War II, there was minimal direct contact between the peoples of the UK and USSR. After the death of Stalin, contacts began to expand but remained patchy. Consequently, in the British popular imagination the Soviet Union was a mysterious, 'half known' place. The British public had pre-formed ideas of the standard and character of Soviet life gleaned from sources including news reports, literature and pre-Cold War perceptions. ${ }^{15}$ The ambivalent attitude of one 1965 Pathé newsreel is typical, portraying the Soviet people as a fascinating but unknowable 'other'. Documenting a National Theatre visit to Moscow, the narrator asks: 'How do they live, these mysterious human beings, once our wartime allies but always an unknown quantity to us?'16

From the late 1950s, growing cultural links to the USSR prompted lighthearted travel literature on the Soviet Union. British journalists and writers who took rare trips to the country wrote of their encounters with Soviet bureaucracy, characters and culture. ${ }^{17}$ Svetlana Boym notes that such

towards a hoped-for improved future. Susan Buck-Morss, Dreamworld and Catastrophe: The Passing of Mass Utopia in East and West (Cambridge, Massachusetts, 2000), pp. x-xi.

12 Ibid., p. 238.

13 Evgeny Dobrenko, 'The Soviet Spectacle: The All-Union Agricultural Exhibition', in Valerie A. Kivelson and Joan Neuberger (eds.), Picturing Russia: Explorations in Visual Culture (New Haven and London, 2008), pp. 189-90.

14 Alistair Cooke, Manchester Guardian (1 July 1959), quoted in David Caute, The Dancer Defects: The Struggle for Cultural Supremacy During the Cold War (Oxford, 2003), p. 41.

15 James Morris, 'Stranger in Sputnik Russia', The Guardian (7 April 1960).

16 Pathé newsreel 'Moscow 1965', 18 November 1965 CP 569 film ID 345.04, www. britishpathe.com [accessed 7.10.2007].

17 e.g. Fred Basnett, Travels of a Capitalist Lackey (Watford, 1965). 
accounts, 'while quite unreliable as historical documents, are exemplary texts of cross-cultural mythology'.18 It is significant that ideas about the USSR often revolved around the perceived unavailability of modern artefacts and low quality of consumer or luxury goods. Such objects were an essential part of the Western consumerist self-image during the Cold War; thus, they were assumed to be absent in its 'mirror opposite', the Eastern Bloc. ${ }^{19}$ At the 1959 American exhibition in Moscow, one Russian woman indignantly wrote in the visitors' book that they were being shown 'pots and kettles, frying pans and shoes, as if we were savages'. ${ }^{20}$ These stereotypes of a 'backward' Russia were often qualified by 'real' travellers tales, which gave a more considered picture of life in the USSR, yet in the West the popular stereotype remained. ${ }^{21}$ Soviet consumer goods were portrayed as difficult to obtain, poorly designed and faulty. Michael Frayn commented in 1959 on many Westerners' 'unreasonable surprise' that the Soviets had such modern conveniences as buses, shoes and electric razors. ${ }^{22}$

These stereotypes were so ingrained that never having visited Russia was no impediment to describing life there. One invented 'traveller's tale' originally from Punch magazine-By Rocking Chair Across Russia (1960)gently mocked the inferior nature of Soviet material culture. This fabricated adventure resonated because it was grounded in a popular Western notion of an underdeveloped Soviet Union. ${ }^{23}$ One excerpt from the satirical serialisation centred on an extensive list of useless Soviet artefacts ranging from the mundane to the military:

[...] Sugar basins are made of some strange, soft metal, and will not bounce. Glue is not sticky enough. Men's hats are a different shape from men's heads: they make your ears stick out [...] middle C sharp sounded flat on

18 Svetlana Boym, Common Places: Mythologies of Everyday Life in Russia (Cambridge, Massachusetts, 1994), pp. 24-5.

19 Patrick Major and Rana Mitter, 'East Is East and West Is West? Towards a Comparative Socio-Cultural History of the Cold War', in Patrick Major and Rana Mitter (eds.), Across the Blocs: Cold War Cultural and Social History (London and Portland, 2004), pp. 1-22.

20 Susan E. Reid, 'Who Will Beat Whom? Soviet Popular Reception of the American National Exhibition in Moscow, 1959', Kritika: Explorations in Russian and Eurasian History, IX, no. 4 (2008), p. 895.

21 Reid notes how the Soviet discourse surrounding the American exhibition of 1959 'reversed this developmental hierarchy', portraying the Socialist East as advanced and civilised, and the USA as 'regressive' (Reid (2008), p. 899).

22 Michael Frayn, 'Material Progress - Victorian Taste: Russia after Two Years', The Guardian, 7 April 1959.

23 A complementary volume satirising the USA was also published. Alex Atkinson and Ronald Searle, Russia for Beginners: By Rocking Chair across Russia (London, 1960). 
most of the pianos I tried. The only inter-continental ballistic missile I saw was made partly of stiff cardboard, and would very likely blow inside out in a high wind... ${ }^{24}$

The list continued with ludicrous Soviet 'triumphs', strangely prescient of some of the bizarre exhibits at Earls Court the following year, including false hair, wooden ink-wells, sound-proofing, currant bread, half-inch castiron ball-bearings, jig-saw puzzle replacements, tortoiseshell earrings, twoway retractable flange compressors in laminated termite-proof lignite and plastic egg-separators. ${ }^{25}$

To a British public raised on such perceptions, the Soviet Earls Court shows were intriguing, popular spectacles. As such, they attracted large audiences and were widely covered across the press. ${ }^{26}$ The Daily Worker regarded the 1961 show as the 'next best thing to a visit to the Soviet Union', ${ }^{27}$ whilst The Sun newspaper described the 1968 exhibition as a 'powerful advert for the Soviet way of life'. ${ }^{28}$ Nonetheless, these exhibitions took place at a time when the British government was committed to fighting the Cold War at home and abroad. ${ }^{29}$ The first show was organised amidst tense incidents including the Paris Peace summit of May 1960 and the US invasion of the Bay of Pigs in April 1961. As the exhibition approached, anxiety over Berlin grew; a matter of weeks after it closed, the Berlin Wall was constructed. Against this backdrop of high-level Cold War politics, trade-the British motivation for this exchange of exhibitions-occupied an ambiguous position. On the one level it was a practical necessity; on the other, an ideological and political issue with deep Cold War significance. Both Britain and the USSR cited trade as a means to promote 'mutual understanding. ${ }^{30}$ Unlike the USA, Britain was more willing to trade with the USSR, a valuable non-dollar market, and had a long history of commercial links with Russia. From the mid-1950s, commerce grew, ${ }^{31}$

24 Ibid., p. 26.

25 Ibid., p. 27.

26 The 1961 exhibition attracted over half a million visitors.

27 'Sputniks and Sideboards coming to Town', Daily Worker, 15 Feb 1961.

28 The Sun was initially a left-wing newspaper (1964-9). 'Russia Today - Tomorrow', The Sun, n.d. August 1968.

29 Michael F. Hopkins et. al., 'Introduction', in Michael F. Hopkins, Michael D. Kandiah and Gillian Staerk (eds.), Cold War Britain 1945-64: New Perspectives (Basingstoke, 2003), p. 4.

30 Michael Kaser, 'Trade Relations: Patterns and Prospects', in Alex Pravda and Peter J. S. Duncan (eds.) Soviet-British Relations since the 1970s (Cambridge, 1990), p. 193.

31 'East West Salesmen', The Guardian, 22 May 1960. 
culminating in the 1959 bilateral agreement to expand and diversify AngloSoviet trade. ${ }^{32}$

Resulting from this agreement, the British organisers initially believed that the Soviet show was a trade show, a reciprocal event for the British Fair held in Sokol'niki Park in May 1961. ${ }^{33}$ Whereas dealings on the Soviet side were state-organised by the All-Union Chamber of Commerce, ${ }^{34}$ on the British side the exhibitions were negotiated by private commercial groups: Industrial Trade Fairs Ltd (ITF) and the Association of British Chambers of Commerce. ${ }^{35}$ However, the 'strict reciprocity' insisted upon at the signing of the contracts proved unworkable. The agreed 'trade fair' became a more ambiguously titled 'Soviet Industrial Exhibition'. ${ }^{36}$ Earlier Soviet assurances that the exhibitions would be 'business-like affairs' and 'should not be used for political propaganda' proved hollow. ${ }^{37}$ The Foreign Office was shocked when press reports revealed the Soviets' 'full scale national exhibition' planned in $1961 .{ }^{38}$ But this should not have been a surprise: most government-sponsored Soviet international exhibitions of the later 1950s and early 1960s described as 'industrial' or 'trade' fairs comprised broadly similar 'way of life' exhibits. The Soviet pavilion at the Brussels Expo of 1958 had set the model for subsequent prestige shows. Its thematic divisionsbeginning with science, industry, agriculture and transport before moving on to themes such as education, food, arts and fashion-were almost identical to the form of the Earls Court exhibitions in 1961 and 1968. ${ }^{39}$ Exhibits were recycled: a visitor to bilateral Soviet exhibitions in New York (1959), Mexico (1959), Norway (1960), Japan (1961) and London (1961) could be forgiven for experiencing déjà vu, repeatedly encountering models of the atomic icebreaker ship 'Lenin' and ubiquitous bleeping sputniks. ${ }^{40}$

32 Curtis Keeble, 'The Historical Perspective', in Pravda and Duncan (1990), p. 37.

33 Kaser in Pravda and Duncan (1990) pp. 197-9.

34 'Britain and Russia Plan Trade Fairs: Moscow Delegation in London', The Times, 12 December 1959.

35 As a subsidiary of the Financial Times, ITF was well placed to promote issues of AngloSoviet trade. TNA FO371/159603 NS1861/47A Commercial Dept, British Embassy Moscow to Foreign Office (July 12 1961)'; TNA FCO28/436 no. 2054 from Foreign Office to Moscow (5 August 1968).

36 TNA FO371/159601 NS1861/11 R.H. Mason (2 March 1961).

37 TNA FO371/159601 NS1861/11 no. 1609 Sir Frank Roberts, British Embassy, Moscow to Foreign Office (17 November 1960).

38 TNA FO371/159601 NS1861/11 R.H. Mason (2 March 1961).

39 Guide to the USSR Pavilion (Brussels, 1958).

40 TNA FO371/159601 NS1861/17 'Organisation of Soviet Foreign Exhibition and the functions of the Soviet Chamber of Commerce'; Brigitte Schroeder-Gudehus and David Cloutier, 'Popularizing Science and Technology During the Cold War: Brussels 1958', in 


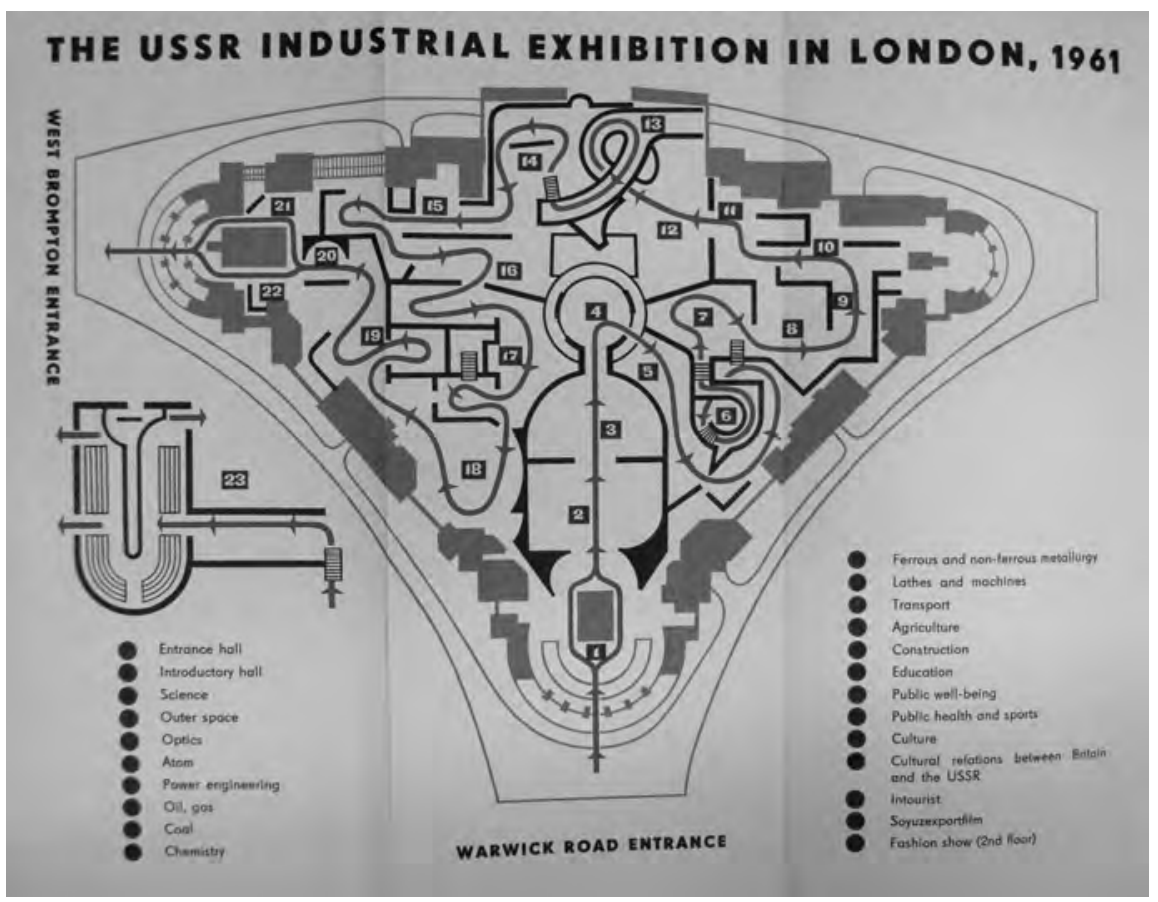

Fig. 20.2 Plan of the first Soviet Earls Court exhibition (1961). Exhibition guide. EC \& O Venues Archive.

In London, responses were divided over the successfulness of these Soviet display techniques, often comparing them unfavourably with Western ones. Some were seen as clumsy, old fashioned or blatantly propagandist, undermining the effectiveness of the illusion of a Soviet 'dreamworld'. In 1961, the huge scale and proliferation of exhibits posed problems for the Soviet designers. 10,000 exhibits were arranged in a warren-like maze covering $23,000 \mathrm{~m}^{2}$-larger than the Soviet pavilion at Brussels-that didactically guided the visitor through twenty-two halls in sequence (fig. 20.2).

Unsurprisingly, this layout was overwhelming and tiring. Whilst the organisers may have intended the cumulative weight of exhibits to indicate growing Soviet material wealth, in their proliferation they became meaningless and bewildering: the critic Lawrence Alloway bemoaned the lack of a vista to survey the whole show, describing 'profusion shading into confusion $[\ldots]$ the halls were crowded together, leaking into each

Robert W. Rydell and Nancy E. Gwinn (eds.) Fair Representations: World's Fairs and the Modern World (Amsterdam, 1994), p. 169. 
other, so there was no respite, no breathing space'. ${ }^{41}$ A Foreign Office report condemned the aesthetic as too serious, old fashioned and lacking in taste, typified by a giant polystyrene bust of Lenin, capitalised statements of platitudes and a statistical onslaught of upward pointing graphs. ${ }^{42}$ Alloway wryly drew attention to the illusion: triumphant graphs 'extrapolated into the future'. ${ }^{43}$ The Observer thought it lacked 'the gloss of the familiar western style exhibition'. ${ }^{44}$ But some saw progress in Soviet display techniques since the 'depressingly heavy handed' styles of Brussels. ${ }^{45}$ Ignoring Lenin's visage, the mixture of 'eye catching' displays and 'glamour girls' at Earls Court could challenge British stereotypes of a dour, old-fashioned USSR. ${ }^{46}$ Some techniques were quite sophisticated, utilising a variety of modern media devices. One hall contained a multi-screen display with fifteen continuous projectors; ${ }^{47}$ another used colour closed circuit television, resulting in an 'atmosphere of discovery and movement'. ${ }^{48}$ The darkened 'Hall of the Cosmos', a key area of the 1961 exhibition, comprised a 100foot high cylindrical display recreating the impression of being in space via model spaceships, five simultaneous films, a revolving globe and musical accompaniment. ${ }^{49}$ The official Foreign Office verdict-'an ambitious project somewhat spoiled by vulgar presentation and mechanical breakdowns' - suggests that this display was less successful in practice..$^{50}$ The 8000 exhibits in 1968 were similarly organised on 'a truly heroic scale'. ${ }^{51}$ Press photographs support Design magazine's assertion that the design of this new show displayed 'a far lighter touch [...] in breaking the various exhibition areas up into manageable proportions' ${ }^{52}$ A large central space,

41 Alloway (1961), pp. 44-6.

42 TNA FO371/159603 NS1861/60 'Assessment of the impressions made by the Soviet Trade Exhibition', Northern Dept, Foreign Office to British Embassy Moscow' (8 September 1961).

43 Alloway (1961), pp. 44-6.

44 John Davy, 'From Space to Murals', The Observer, 9 July 1961.

45 'Soviet Display', The Guardian, 8 July 1961; Rene Elvin, 'Fair enough or fair too much?', Art and Industry, LXV, no. 387 (September 1958), pp. 74-83.

46 Michael Moynihan, 'Russia Brings Sputniks and Glamour Girls', The Observer, 2 July 1961.

47 'Films at the Soviet Exhibition', British Kinematography, XXXIX, no. 3 (September 1961), p. 80.

48 'Propaganda by Caviare, Wines and Sputniks: 10,000 exhibits in Soviet Show', The Guardian, 7 July 1961.

49 'Sputniks "In Orbit" At Exhibition: Soviet £1m drive in London', The Times, June 301961.

50 TNA FO371/159603 NS1861/60, 'Assessment of the impressions...'

51 'Russia on Show', Evening Standard, 6 August 1968.

52 'Bumper Russian display at Earls Court', Design, no. 236 (August 1968), p. 13. 
200 feet in diameter, contained the prized space hardware, around which a series of interlinking exhibition halls were grouped..$^{53}$

The 'dreamworlds' presented at the Earls Court exhibitions were comprised of Soviet objects. Eager British audiences wanted to extrapolate a picture of little-known Soviet lives from the displays of homes, education and culture on view at Earls Court. The Daily Worker summed up the content as 'sputniks and sideboards ${ }^{\prime 54}$-that is, technology and consumer goods..$^{55}$ Yet their reception was often conditioned by preconceived British notions of 'ideal' Soviet objects. Whilst spaceships and satellites were almost universally celebrated in both 1961 and 1968 as Soviet objects par excellence, consumer goods received a more mixed response. Frequently, exhibits were criticised for emulating Western originals. Whilst this was sometimes with good cause-Soviet objects were often substitutes copying 'forbidden products from the west' ${ }^{\prime 5}$ - responses at Earls Court emphasised the inferiority of these imitations. Parallel to this ran a British discourse of what an ideal Soviet object should be, drawing on notions of traditional folk and craft cultures. ${ }^{57}$ Underlying this were constant reminders from journalists and reviewers that the 'way of life' shown at Earls Court was an illusion; such objects were unobtainable for ordinary Soviet people..$^{58}$

Technological superiority was a 'potent symbol' for both East and West in the competitive arena of the Thaw: in 1961, over half the exhibition space was occupied by science, engineering and industry. ${ }^{59}$ Alongside the celebrated space exhibits, visitors had to negotiate countless examples of tractors, lathes and drilling equipment to gain access to the fashion, education, and public health areas. ${ }^{60}$ Gleaming satellites were the primary

53 TNA FCO28/436 'Press release: The Soviet Exhibition Comes to Town'.

54 'Sputniks and Sideboards coming to town', Daily Worker, 15 Feb 1961.

55 TNA FCO28/436 'Press release: The Soviet Exhibition Comes to Town'; Reuter's newsreel ref BGY504090073 (6 July 1961) www.itnsource.com [accessed 10.6. 2007].

56 Hildi Hawkins, 'Superfluous Things', Things, no. 4 (Summer 1996), p. 141.

57 The Soviet authorities actively promoted a civilised and refined type of folk art. Wendy Salmond, 'Reviving Folk Art in Russia: The Moscow Zemstvo and the Kustar Art Industries,' in Nicola Gordon Bowe (ed.), Art and the National Dream: The Search for Vernacular Expression in Turn of the Century Design (Dublin, 1993), pp. 81-98.

58 Hawkins notes the commonplace 'emptiness' of Soviet shops in the 1970s and 1980s (Hawkins, p. 141).

59 'Introduction', Reid and Crowley (eds.) (2000), p. 9.

60 The twenty-two sections were: 1. Entrance Hall, 2. Introductory Hall, 3. Science, 4. Outer Space, 5. Optics, 6. Atom, 7. Power Engineering, 8. Oil, Gas, 9. Coal, 10. Chemistry, 11. Ferrous and non-ferrous metallurgy, 12. Lathes and machines, 13. Transport, 14. Agriculture, 15. Construction, 16. Education, 17. Public well-being, 18. Public health and sports, 19. Culture, 20. Cultural Relations between Britain and the USSR, 21. Intourist, 
attraction for a British public newly captivated by space exploration: Iurii Gagarin's historic space flight occurred mere weeks before the 1961 show. ${ }^{61}$ The British press eagerly seized upon the forthcoming opportunity to see life-size replicas of sputniks and luniks. One commentator anticipated 'splendid space age fun', seemingly negating any Cold War nuclear anxieties surrounding the space race. ${ }^{62}$ Another stated that 'The British public [...] should find it a thrilling experience' ${ }^{63}$ Such responses were further heightened by the extremely popular visit of Gagarin to Britain to coincide with the exhibition. ${ }^{64}$ On his first trip to Western Europe, the cosmonaut received a hero's welcome bordering on the hysterical, boosting attendance at Earls Court. ${ }^{65}$ Although some journalists warned that this response did not 'refute the Cold War', ${ }^{66}$ Gagarin was an enormously valuable representative of the Soviet regime: 'never has Moscow sent a finer ambassador', commented one newsreel. ${ }^{67}$

Responses to other scientific exhibits were less favourable. While there was a general consensus that the displays were impressive, the lack of clear explanations of mysterious machinery caused consternation. ${ }^{68}$ In 1968, the British press ridiculed bizarre - possibly mistranslated - Soviet gadgets like 'equipment for the reanimation of patients in a state of clinical death' and an 'electronic sleep machine'. ${ }^{69}$ But there were also technical innovations which appealed to modern Western lives: a miniature transistor radio called the Micro, designed to be worn like a badge, aroused favourable press response. ${ }^{70}$

Particularly in 1961, consumer goods, architecture and transport were keenly received. Audiences were curious to see objects that supposedly offered an insight into the lives of ordinary Russians, though most British newspapers stressed that the fashions and electrical appliances were frequently prototypes and unavailable to the population at large.

22. Soyuzexportfilm; and, on the upper floor, a Fashion Show. 'The USSR Industrial Exhibition in London, 1961' Guide, Private collection.

61 'New and Old From Russia', The Times, July 101961.

62 John Davy, 'From Space to Murals', The Observer, 9 July 1961.

63 'Propaganda by Caviare, Wines and Sputniks: 10,000 Exhibits in Soviet Show', The Guardian, 7 July 1961.

64 'Sputniks 'In Orbit' At Exhibition: Soviet $£ 1 m$ Drive in London', The Times (June 30 1961).

65 Gagarin was the 'prize attraction'. The Guardian, 8 July 1961.

66 'Cheers to the End for Gagarin', The Guardian, 16 July 1961.

67 Reuters newsreel REF: BP170761173205 17/07/1961, 'Hail Gagarin', www.itnsource.com.

68 'Space Highlights at Soviet Exhibition', Daily Telegraph, 7 August 1968.

69 TNA FCO28/436 'Press release: The Soviet Exhibition Comes to Town'.

70 'The Russians Send Dazzling Space Display', Evening Standard, 2 August 1968. 
Preconceived notions of Soviet goods as scarce and shoddy could colour responses. ${ }^{71}$ The general reaction to both 1960s exhibitions was that the consumer goods tended to look 'sturdy rather than elegant'. ${ }^{22}$ As Robert Haddow's thoughts on the post-war US economic system suggest, such sturdiness was antithetical to capitalist goods which prioritised style and elegance as well as planned obsolescence. ${ }^{73}$ A confidential Foreign Office report of 1961 condemned a vast swathe of the china, glass, textiles and carpets as being of 'inferior standard and poor taste'. ${ }^{74}$ Similarly, Design magazine's overall impression was of a 'chaotic collection of poorly designed and [...] badly produced articles'. However, it praised some exhibits that fitted its modernist agenda, notably a 'delightfully clean and satisfying design' for a Moscow cinema and some 'simple' and 'restrained' children's furniture. ${ }^{75}$

British responses suggest a belief in a characteristic Soviet style defined in opposition to the products of the West. Many British commentators thought artefacts from the USSR should reflect this identity and not try to imitate modern Western goods. This 'typical' Soviet object was often conflated with ideas of decorative, traditional folk crafts, like those stocked at the Russian Shop in Holborn. ${ }^{76}$ It was where the USSR was portrayed as having copied Western designs that the British press was most critical. In 1961, televisions and cars were condemned for copying dated stylistic devices from the USA and Italy. ${ }^{77}$ Similarly, in 1968 the $12 \mathrm{~m}$ long model of a prototype Soviet supersonic airline, the TU 144 drew adverse attention. ${ }^{78} \mathrm{It}$ was later nicknamed 'Concordski' amid accusations of industrial espionage. Such allegations of plagiarism were by no means confined to machines and appliances. A women's column in The Times criticised derivative china, glass and textiles: 'When the Russians are themselves, it seems, their designs are

71 Contrast Boym's analysis of how objects were negotiated in Russian communal apartments (Boym (1994) p. 158).

72 'Russia Today - Tomorrow', The Sun, n.d. August 1968.

73 I am grateful to Dr Lesley Whitworth for noting the value judgements implicit in the term 'sturdy'. Robert H. Haddow, Pavilions of Plenty: Exhibiting American Culture Abroad in the 1950s (Washington, 1997), p. 5.

74 TNA FO371/159603 NS1861/60 'Assessment of the impressions...'

75 Fred Ashford, 'USSR at Earls Court: Products', Design, no. 154 (October 1961), pp. 47-9.

76 The December 1968 edition of Homes and Gardens continued to carry advertising for the Russian Shop - 'Unusual gifts for Xmas from Russia' - with an illustration of Matrioshka dolls.

77 Alloway (1961), pp. 44-6.

78 TNA FCO28/436 translation of article 'At Earls Court', Izvestiia (2 August 1968). 
excellent. But in things feminine, at least, when they too plainly copy the West, the West still does best. ${ }^{79}$

Similar views extended to the daily Soviet fashion shows at Earls Court. Some took them at face value: a 1961 Pathé newsreel expressed surprise at the fashions, stating that 'clearly Russian women have become dress conscious to a surprising extent'. ${ }^{80}$ The degree of shock at 'smart, attractive, up to date clothes' and 'unexpectedly frivolous hats' indicates how startling they were to British expectations. ${ }^{81}$ This glamorous, ideologically constructed style, identified by Djurdja Bartlett as the 'official socialist dress' style of 1958-68, bore little relationship to the reality of shortages and poor quality affecting everyday clothing for the majority of Soviet women. ${ }^{82}$ The Times commented that the 1961 displays should challenge western stereotypes of dowdy Soviet women 'miserably clad in out-of-date dresses and suits', but stressed that most fashions would be unobtainable. ${ }^{83}$

Conversely, those artefacts perceived by British observers to be typically 'Russian' were widely praised. Responses to the 1961 fashions regarded 'traditional designs' with a peasant influence, such as fringed and braided skirts, folk-inspired embroidery and furs, as 'beautiful' and 'new'. ${ }^{84}$ Those items that reflected a Western idea of Russian traditions won the greatest approval. ${ }^{85}$ Stereotypes of dowdy Russian women ${ }^{86}$ continued to inform judgements: in 1968 the Daily Mail was surprised that the clothing was 'decidedly feminine, very much in fashion'. ${ }^{87}$ Garments displayed a blend of the modern and the traditional, including some space age jumpsuits ${ }^{88}$ mixed with clothing which many reporters thought mimicked Western styles: '[O]nly the modest hemlines gave the game away'. ${ }^{9}$

79 'New and Old From Russia', The Times (10 July 1961).

80 Pathé newsreel 'Russia Opens Trade Fair', 1961, Film ID: 1730.24, www.britishpathe.com [accessed 7.10.2007].

81 Katherine Whitehorn, 'The Soviet Exhibition - the Fashions', The Observer, 9 July 1961.

82 Djurdja Bartlett, 'Let Them Wear Beige: The Petit-Bourgeois World of Official Socialist Dress', Fashion Theory. The Journal of Dress, Body and Culture, VIII, no. 12, pp. 127-64 (p. 134).

83 'New and Old From Russia', The Times, July 101961.

84 Ibid.

85 Ibid.

86 Stephen Wagg, "If You Want the Girl Next Door..." Olympic Sport and the Popular Press in Early Cold War Britain', in Stephen Wagg and David L. Andrews (eds.), East Plays West: Sport and the Cold War (London and New York, 2007), pp. 100-22.

87 'The Modest Revolutionaries Put Moscow on the Fashion Map', Daily Mail, 5 August 1968.

88 'Out of This World', Morning Star, 6 August 1968.

89 'Modest Revolutionaries', Daily Mail, 5 August 1968. 
Reactions to the displays and exhibits at Earls Court indicate that the Soviet 'dreamworld' on display could be enjoyed as a mere spectacle, a 'make-believe' place distanced from the reality of Cold War politics. British commentators frequently returned to themes of dreaming, fantasy and childhood. In 1968, The Times stated, 'this is a child's exhibition, with its avenues of glittering, incomprehensible machines' ${ }^{90}$ A Reuter's newsreel of 1961 commented on 'a great emphasis on children throughout the exhibition [...]. A glittering fairyland of dolls and toys' ${ }^{91}$ The Sun described the 1968 Hall of the Cosmos as 'a schoolboy's paradise'.$^{92}$ In suggesting that the imagined 'way of life' on display at Earls Court was an illusion appropriate for children, British commentators deprived it of its political power. The Soviet dreamworld was not merely fantasy; it was a child's fantasy: naïve and unthreatening.

This vision of Soviet life was well received precisely because it was imaginary. Press reports encouraged visitors to disregard the 'propaganda nowadays inseparable from prestige exhibitions of national achievements' ${ }^{93}$ The British government asserted that no sensible Briton would take this vision at face value. Soviet pamphlets distributed in 1961 remained uncensored, the Foreign Office asserting that:

We believe the British public are intelligent enough not to be swept off their feet by the obvious fallacies and half-truths which are contained in the literature being distributed at Earls Court. ${ }^{94}$

Nevertheless, the Information Research Department (IRD) of the Foreign Office felt it necessary to advise politicians and press how to counteract the Soviet propaganda inherent in the exhibitions by stressing trade motives, and emphasising the fallacy of Soviet claims to peace, freedom and high living standards. ${ }^{95}$

Perhaps this association with childish fantasy explains why the 1961 exhibition attracted surprisingly little controversy despite the political context. ${ }^{96}$ However, this illusion of an unthreatening socialist utopia

90 Byron Rogers, 'People's Guide to Russia: Mr Wilson Toasts Peace and Trade', The Times, 7 August 1968.

91 Reuter's ref BGY504090073 (6 July 1961), www.itnsource.com [accessed 10.6. 2007].

92 'Russia Today - Tomorrow', The Sun, n.d. August 1968.

93 'New and Old From Russia', The Times, 10 July 1961.

94 TNA FO371/159603 NS1861/51 Foreign Office to Lloyd Jones (24 July 1961).

95 TNA FO371/159603 NS1861/48 INTEL No 81 `The Soviet Exhibition - its scope and effect - points to keep in mind' (4 July 1961).

96 TNA FO371/159602 NS1861/35 JL Bullard, 'Soviet Exhibition in London' (9 June 1961). 
evaporated during the 1968 show. ${ }^{97}$ The opening had been received cordially in Britain. Banners declaring the familiar rhetoric of 'Peace' and 'Friendship' dominated the entrance hall. But the invasion of Czechoslovakia in the final week of the exhibition prompted 'considerable' demonstrations ${ }^{98}$ up to 1500 strong outside Earls Court and vandalism within. ${ }^{99}$ Attendancealready half that of 1961 -dropped dramatically. ${ }^{100}$ Proclamations of peace and friendship could do little to counteract news reports of actual Soviet aggression. ${ }^{101}$ Even British attendees from communist households saw their illusions shattered. Phil Cohen, working at the exhibition's Russian Shop outlet, recalls:

One morning I walked the gauntlet of demonstrators protesting at the Soviet tanks rumbling into Czechoslovakia to crush the Prague Spring. Inside there was a strange atmosphere, with protestors rushing around shouting at us; one log cabin was set on fire. I suddenly felt uneasily that I was in the wrong place. I stopped going after that. ${ }^{102}$

Upon closure, the director of ITF described the exhibition as 'quite useless' to the Soviet Union. ${ }^{103}$

The 1961 Soviet exhibition had been a rare and popular 'glimpse of a contradictory and fascinating country' ${ }^{104}$ Life in the mysterious USSR had been brought to Britain via space technology and socialist consumer goods. Yet the dreamworld of the 1968 exhibition vanished in the face of Soviet military aggression. By the time of the final exhibition, these shows had faded from well-attended, popular spectacles which aroused playfully positive responses, to a minor diversion for a limited audience. Held in May 1979, the old, familiar themes were present: posters proclaimed 'Peace and Progress through Cooperation' and it was designed to 'strengthen trade links' and give an insight into the 'way of life' of the USSR. The Telegraph described a 'guarded welcome for Russia' at this 'USSR National Exhibition'.

97 'Into Dreamland', The Guardian, 22 August 1968.

98 TNA FO28/436 File NS 6/10 I. Trafford, ITF Ltd to P.T. Hayman, Foreign Office (30 August 1968).

99 Newsreel 'Russians Invade Czechoslovakia' Ref: T21086801, www.itnsource.com [accessed 5.12.2006].

100 Prior to the invasion, attendances were 11,103 per day compared to 25,688 per day in 1961. Following the invasion they averaged 6,415 per day, with a low of 4,347 . TNA FO28/436 NS6/10 Trafford to Hayman (30 August 1968).

101 'Soviet Exhibition Attendance Slumps', The Guardian, 23 August 1968.

102 Phil Cohen, Children of the Revolution: Communist Childhood in Cold War Britain (London, 1997), pp. 25-6.

103 TNA FO28/436 NS6/10 Trafford to Hayman (30 August 1968).

104 John Davy, 'From Space to Murals', The Observer, 9 July 1961. 
Less than half the size of the first show $\left(11,000 \mathrm{~m}^{2}\right)$, it had little appeal to the public: one press headline punned that there was "Nobody "Russian" to See the Show' ${ }^{105}$ The triumphant exhibitions of the 1960s seemed to have been forgotten: newspaper reports returned to clichés such as the 'lifting of the Iron Curtain'. Some even suggested that this was the first exhibition of its kind. ${ }^{106}$ In the face of half-hearted displays of a frozen baby mammoth, Georgian folk dancers and the Saliut space station, the Evening Standard perceptively commented that:

[...] all exhibitions of national triumphs are instructive in their selectivity

$[\ldots]$ paradoxically, the constant propaganda only serves to remind visitors of the jarring disparity between the image and reality. ${ }^{107}$

The Soviet Earls Court exhibitions had aimed to present an idealistic vision of the 'way of life' of the USSR. This had been accepted by the British press on the proviso that it was an entertaining illusion, easily integrated with pre-existing British ideas of the mysterious Soviet Union. By 1979, this had failed: the gap between the 'reassuring myth' of socialist life and political reality was too wide to be accepted by British observers. Despite the surprisingly positive responses of 1961, the fantasy was short-lived. The Foreign Office thought that it did little to challenge British perceptions of the USSR:

[...] we do not believe that it made any significant impression on the public attitude towards the Soviet Union in this country, which would be defined as one of rueful scepticism. ${ }^{108}$

In 1961, the British press and public had been prepared to overlook this 'constant propaganda' in order to marvel at the products and lifestyles of a world largely closed off to them. By 1979, the final, anachronistic show no longer offered exciting glimpses of an intriguing Soviet 'dreamworld'; instead, the once-fascinating sputniks and sideboards merely confirmed entrenched Cold War preconceptions.

105 Exhibitions International (June-July 1979).

106 'Fashioniski!', Luton Evening Post, 23 May1979.

107 [untitled], Evening Standard, 23 May 1979.

108 TNA FO371/159603 NS1861/60 'Assessment of the impressions...'. 